\title{
Molecular characteristics of representatives of the genus Brachylecithum Shtrom, 1940 (Digenea, Dicrocoeliidae) with comments on life cycle and host specificity
}

\author{
Joanna Hildebrand $^{1}$ - Jilji Sitko ${ }^{2}$ - Grzegorz Zaleśny ${ }^{3}$ - Witold Jeżewski ${ }^{4}$. \\ Zdzisław Laskowski ${ }^{4}$
}

Received: 10 November 2015 / Accepted: 7 December 2015 /Published online: 28 December 2015

(C) The Author(s) 2015. This article is published with open access at Springerlink.com

\begin{abstract}
The genus Brachylecithum was for the first time subject to molecular taxonomic phylogenetic analysis in order to ascertain relationships among its component taxa. We used two markers - the nuclear ribosomal $28 \mathrm{~S}$ ribosomal DNA (rDNA) gene and the mitochondrial cox 1 gene, for six species of the genus; 11 sequences of partial $28 \mathrm{~S}$ rDNA and partial cox 1 were obtained from adult $B$. capilliformis, B. glareoli, B. kakea, B. laniicola, B. lobatum, and B. strigis, and from larval stages obtained from snails of the genus Cepaea. We propose to synonymize $B$. strigis with $B$. lobatum, while the genetic differences in the 28S rDNA gene and mitochondrial cox 1 gene confirm the species status of $B$. capilliformis and indicate a distinct group within Brachylecithum, including $B$. kakea and B. laniicola. Cercarial and metacercarial isolates from the snails showed $100 \%$ similarity to B. lobatum; thus, it is the first record of Cepaea snails as intermediate hosts of this species and the first report on life cycle abbreviation within the Dicrocoeliidae.
\end{abstract}

Keywords Digenea $\cdot$ Dicrocoeliidae $\cdot$ Brachylecithum . Molecular phylogeny $\cdot$ Life cycle abbreviation

Joanna Hildebrand

joanna.hildebrand@uwr.edu.pl

1 Department of Parasitology, Institute of Genetics and Microbiology, University of Wrocław, Przybyszewskiego 63,

51-148 Wrocław, Poland

2 Comenius Museum, Horní nám. 7, 75011 Přerov, Czech Republic

3 Department of Invertebrates Systematic and Ecology, Institute of Biology, Wrocław University of Environmental and Life Sciences, Kożuchowska 5b, 51-631 Wrocław, Poland

4 Institute of Parasitology, Polish Academy of Sciences, Twarda 51/55, 00-818 Warszawa, Poland

\section{Introduction}

Species of the family Dicrocoeliidae Looss, 1899 complete their life cycle on land. Adults mainly parasitize the bile ducts and gall bladders of birds and mammals. The family is speciose and shows a high level of morphological variability or phenotypic plasticity. In her review of the Dicrocoeliidae, Pojmańska (2008) stated that the great variation of body shape, size, and topography of the internal organs made it difficult to propose an unambiguous classification system; consequently, different authors proposed several taxonomic arrangements. The family's classification was modified on several occasions; new genera, subfamilies, or tribes were proposed, and species were transferred between genera by, for example, Shtrom, Travassos, Skrjabin and Evranova, Yamaguti, Odening, or Panin (Pojmańska 2008). The most recent classification of the group is mainly based on adult morphological characters, and knowledge of the biology and life cycles of most species is scanty.

Molecular data on dicrocoeliid genera are incomplete, and phylogenetic analyses among the numerous dicrocoeliid taxa are unclear and often limited to a single species (e.g., Maurelli et al. 2007; Cai et al. 2012). The GenBank contains such data for 17 species (except those of Dicrocoelium and Eurytrema species) for which only sequences of partial $18 \mathrm{~S}$ and $28 \mathrm{~S}$ ribosomal DNA (rDNA) genes are available. The Dicrocoeliidae comprise over 400 species (Pojmańska 2008), and the scarcity of molecular information limits phylogenetic analysis within the family. So far, only publications of Tkach et al. (2001) and Olson et al. (2003) outlined the position of this family among the digeneans, and two studies dealt with individual species in a phylogenetic context: Ribas et al. (2012) on Paraconcinnum leirsi from African rodents and Hildebrand et al. (2015) on Lyperosomum sarotruhe from African birds. 
More than 90 representatives of Brachylecithum Shtrom, 1940 were described in Panin's (1984) publication, which is the most recent monograph on the Dicrocoeliidae. However, some of the descriptions were based on single specimens from one locality, and the host specificity was a common criterion in describing new species. The genus Brachylecithum, like Brachydistomum Travassos, 1944, Corrigia Shtrom, 1940, and Lutztrema Travassos 1941, represents the subfamily Dicrocoeliinae, whose life cycles include long-tailed xiphidocercariae which leave their first intermediate host, the land snail, in mucoid balls. Arthropods are the second intermediate hosts. Most experimental studies on the life cycles of Brachylecithum concerned B. alfortense (Railliet, 1900), according to Rysavy (1960) a synonym of B. lobatum; B. americanum Denton, 1945; B. mosquensis (Skrjabin and Isaitschikoff, 1927); B. myadestis Carney, 1972; B. orfi Kingston and Freeman, 1959 and B. stunkardi (Pande, 1939) (Carney 1970, 1972, 1974; Denton 1945; Kingston 1965; Timon-David 1957). It should be emphasized that knowledge of the second intermediate hosts of Brachylecithum is still incomplete. Only Denton (1945) suggested that chrysomelid beetles served as the natural second intermediate hosts of B. americanum. Brachylecithum is one of the largest dicrocoeliine genera whose representatives are found mostly in birds; however, the systematic position of some species, their phylogenetic relationships, and host associations remain unclear.

Our studies yielded new sequence data for the nuclear and mitochondrial markers of ten representatives of Brachylecithum (from various hosts and different development stages). The material came from central Europe. To our knowledge, this study is the first attempt at phylogenetic analysis of relationships within the genus.

\section{Material and methods}

\section{Sample collection}

Adult specimens of Brachylecithum Shtrom, 1940 used in this study were collected and identified during long-term helminthological studies of birds from the Czech Moravia, with some additional birds sampled in Poland (Mazovia Disctrict, Baltic Coast) within parasitological research of the Institute of Parasitology, PAS, and the University of Wrocław. Adult B. glareoli were collected from the bank vole Myodes glareolus live-trapped in the water intake area of Wrocław (Lower Silesia, Poland). Larval stages of Brachylecithum spp. were isolated from land snails Cepaea spp. (Fig. 1) in the Mazovia District during the research on the helminth fauna of slugs and their role in the spread of parasites in natural habitats. In some of the examined specimens of the white-lipped (Cepea hortensis) and brown-lipped snail (C. nemoralis), we found sporocysts with cercariae, while in others the sporocysts contained encysted metacercariae. The larval stages were collected alive, washed in physiological salt solution, heatkilled in tap water, and preserved in $70 \%$ ethanol. Prior to fixation, measurements and photographs were taken with an Olympus DP25 digital camera coupled with an Olympus BX50 light microscope. The adults were identified under the microscope, rinsed in saline and water, and fixed in 70 or $96 \%$ ethanol for further morphological or molecular processing. The names of the dicrocoeliids, their hosts, and localities are listed in Table 1.

\section{DNA extraction, gene amplification, and sequencing}

For molecular analysis, DNA was extracted from ethanolfixed, single specimens of adults, metacercariae, and sporocysts (with cercariae) using the Qiagen DNeasy ${ }^{\mathrm{TM}}$ tissue kit and Genoplast Tissue Genomic DNA Extraction Mini Kit according to the manufacturer's instructions. The partial nuclear ribosomal 28S rDNA (D1-D3) gene was amplified using the forward primer DLS1 and the reverse primer $1500 \mathrm{R}$. The thermocycling profile was as follows: $3 \mathrm{~min}$ denaturation at $94{ }^{\circ} \mathrm{C} ; 35$ cycles of $30 \mathrm{~s}$ at $94{ }^{\circ} \mathrm{C}, 1 \mathrm{~min}$ at $55^{\circ} \mathrm{C}$, and $1 \mathrm{~min}$ at $72^{\circ} \mathrm{C}$; and $10 \mathrm{~min}$ extension at $72{ }^{\circ} \mathrm{C}$. The partial mitochondrial cytochrome $c$ oxidase subunit 1 (cox1) gene was amplified using the forward primers COIA3/COIDF1 and the reverse primers COITR1/COIDR 1 with the following thermocycling profile: 3 min denaturation at $94{ }^{\circ} \mathrm{C} ; 35$ cycles of $30 \mathrm{~s}$ at $94^{\circ} \mathrm{C}, 30 \mathrm{~s}$ at $50^{\circ} \mathrm{C}$, and $1 \mathrm{~min}$ at $72{ }^{\circ} \mathrm{C}$; and $5 \mathrm{~min}$ extension at $72{ }^{\circ} \mathrm{C}$. PCR and sequencing primers are listed in Table 2. The amplified products were purified using a PCR purification kit (Genoplast, Poland) according to the manufacturer's instruction and sequenced directly on an ABI Prism 373xl automated sequencer (Applied Biosystems, USA) using ABI BigDye ${ }^{\mathrm{TM}}$ (Applied Biosystems) by Genomed (Poland). DNA products were sequenced in both directions using the PCR primers and sequencing primers (lsrDNA). Forward and reverse sequences were assembled and aligned using Vector NTI Advance 11.0 (Invitrogen, Life Technologies) software and submitted to GenBank. Accession numbers of adults and larvae are listed in Table 2.

\section{Sequence alignment and phylogenetic analyses}

The first phylogenetic analysis was based on partial $28 \mathrm{~S}$ rDNA gene with the newly generated sequences of Brachylecithum and selected sequences of dicroceoliids from GenBank (Table 1). The nucleotides were aligned with AlignX (Vector NTI Advance 11.0), with default settings. Regions that could not be unambiguously aligned were excluded from the analysis. JModelTest version 2.1.4 (Darriba et al. 2012; Guindon and Gascuel 2003) was used to select 


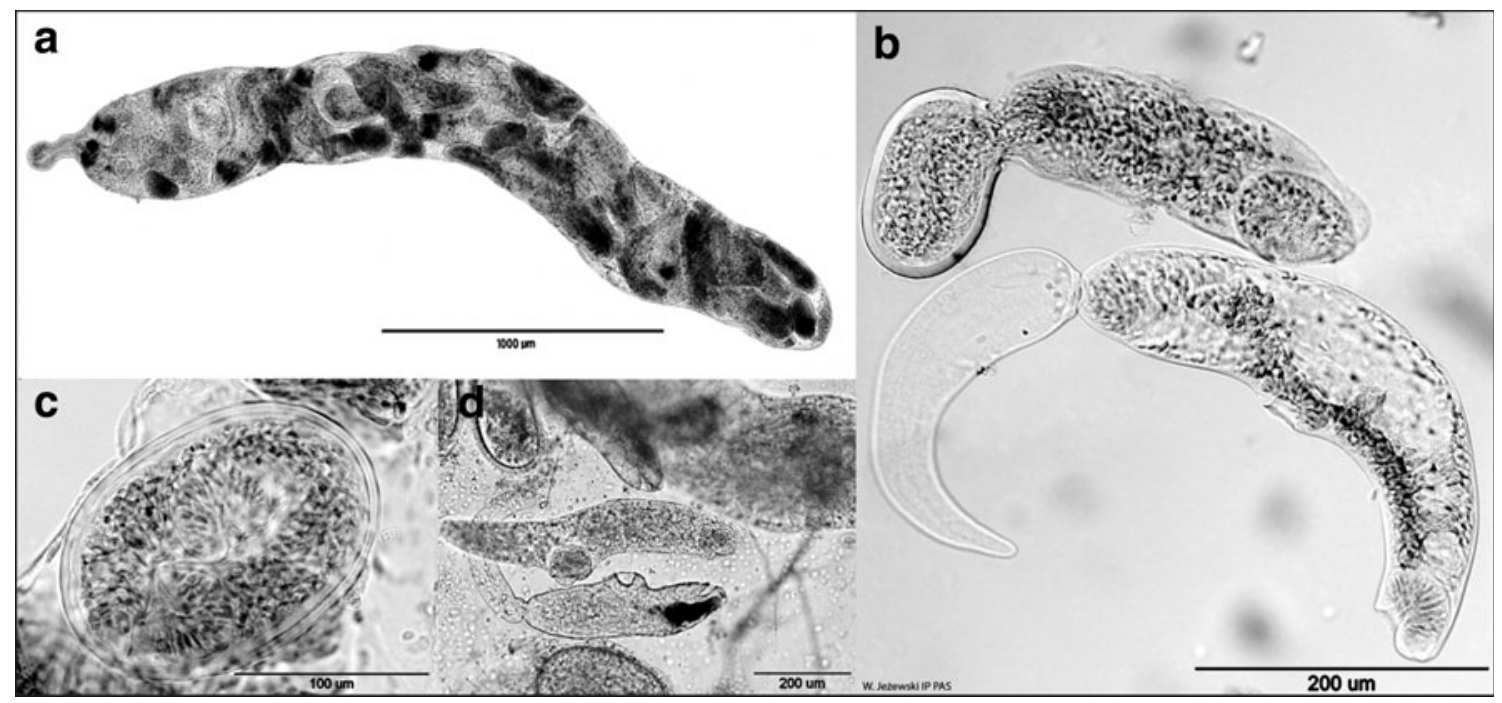

Fig. 1 Larval stages of Brachylecithum lobatum from Cepaea hortensis. a Sporocyst, $\mathbf{b}$ cercaria and metacercaria hatching from the cyst, $\mathbf{c}$ encysted metacercaria, and $\mathbf{d}$ cercaria, free metacercaria, cysts with metacercaria, and fragment of a sporocyst

models of evolution using the Akaike information criterion (AIC). The chosen parameters of the substitution model were GTR + G. Phylogenetic trees were constructed using Bayesian inference (BI) as implemented in the MrBayes program version 3.2 (Ronquist and Huelsenbeck 2003) with Macvicaria magellanica (Opecoelidae) (Laskowski et. al. 2013) as an outgroup.

The sequences of a partial region of the cytochrome $c$ oxidase subunit 1 gene were obtained for adults of Brachylecithum and Lyperosomum as well as from sporocysts, cercariae, and metacercariae isolated from their snail hosts (Table 1). All generated mitochondrial DNA sequences were used in the next analysis using the same parameters and the same software as in the 28S rDNA analysis, with the HKY + $\mathrm{G}+\mathrm{I}$ models of evolution.

Subsequently, partial 28S rDNA sequences were concatenated with partial mitochondrial cox 1 sequences in the second dataset for independent phylogenetic analysis. In mixed analyses $(28 \mathrm{~S}+\operatorname{cox} 1)$, the data were partitioned into two character sets: (1) $28 \mathrm{~S}$ and (2) $\mathrm{mt}$ data as nucleotides. The phylogenetic analysis was carried out using the BI in the MrBayes program. Likelihood settings were set to the $\mathrm{GTR}+\mathrm{G}$ model $(28 \mathrm{~S})$ and $\mathrm{HKY}+\mathrm{G}(\operatorname{cox} 1)$ in accordance with the AIC results. In concatenated datasets, parameters were estimated separately. The analysis of combined sequences of $28 \mathrm{~S}+\operatorname{cox} 1$ was provided with Lyperosomum collurionis as an outgroup (based on 28S rDNA analysis). Phylogenetic trees were visualized using the TreeView software (Page 1996). The evolutionary divergence between the sequences was estimated using MEGA6 software (Tamura et al. 2013); analyses of the number of nucleotide substitutions were conducted using the maximum composite likelihood model (Tamura et al. 2004).

\section{Results}

Eleven partial 28S rDNA sequences (1198 bp) and partial cox 1 sequences ( $388 \mathrm{bp}$ ) were obtained from adult trematodes of the genus Brachylecithum: B. capilliformis, B. glareoli, B. kakea, B. laniicola, B. lobatum, and B. strigis, and from larvae obtained from snails. Additionally, we obtained sequences of $\operatorname{cox} 1$ for adult $L$. collurionis.

The ribosomal sequences of adults of $B$. lobatum from Corvus frugilegus and Accipiter nisus, B. strigis from Otus scops, and all the larval forms (sporocysts, cercariae, and metacercariae) from Cepaea spp. were identical with the sequence of B. lobatum from Corvus cornae previously deposited in the GenBank (AY222260) and with B. glareoli from M. glareolus.

The Bayesian phylogenetic analysis of 28S rDNA generated a phylogenetic tree with all topologies supported by solid (66-99) posterior probability values (Fig. 2), and all members of Brachylecithum were clustered in this tree with $99 \%$ branch support. The tree revealed two well-supported clades. The first included the Lyperosomum group with L. collurionis from the Eurasian blackcap, and the second contained two subclusters: one with Dicrocoelium dendriticum and $D$. hospes, the other with the remaining taxa, i.e., the Brachylecithum group. The members of Brachylecithum formed two clades: one included B. grummti (with weak $54 \%$ branch support) and the other consisted of two clearly separated and well-supported (100\%) clusters, one with B. capilliformis, B. lobatum, B. strigis, and B. glareoli and the other formed by B. kakea and B. laniicola (Fig. 2).

The analysis of the sequences obtained from Brachylecithum showed differences within the $28 \mathrm{~S}$ region of rDNA. The $28 \mathrm{~S}$ rDNA-based estimate of evolutionary 
Table 1 The list of taxa used in this study, host species, geographical origin of material, and GenBank accession numbers

\begin{tabular}{|c|c|c|c|c|}
\hline \multirow[t]{2}{*}{ Digenea taxa } & \multirow[t]{2}{*}{ Host species } & \multirow[t]{2}{*}{ Geographical origin } & \multicolumn{2}{|c|}{ GenBank accession no. } \\
\hline & & & $28 \mathrm{~S}$ & $\operatorname{cox} 1$ \\
\hline Brachylecithum capilliformis Oshmarin, 1952 & $\begin{array}{l}\text { River warbler } \\
\text { Locustella fluviatilis }\end{array}$ & Czech Republic, Central Moravia & KU212184 & KU212182 \\
\hline $\begin{array}{l}\text { Brachylecithum glareoli Hildebrand, Okulewicz and } \\
\quad \text { Popiołek, } 2007\end{array}$ & $\begin{array}{l}\text { Bank vole } \\
\text { Myodes glareolus }\end{array}$ & Poland, Lower Silesia & $\begin{array}{l}\text { KU212201 } \\
\text { KU212203 }\end{array}$ & $\begin{array}{l}\mathrm{KU} 212202^{\mathrm{a}} \\
\mathrm{KU} 212204^{\mathrm{a}}\end{array}$ \\
\hline Brachylecitum grummti Odening, 1964 & $\begin{array}{l}\text { Cinnamon attila } \\
\text { Attila cinnamomeus }\end{array}$ & Brazil & KP765768 & - \\
\hline Brachycecithum kakea (Bhalerao, 1926) & $\begin{array}{l}\text { Great reed warbler } \\
\text { Acrocephalus arundinaceus }\end{array}$ & Czech Republic, Central Moravia & $\begin{array}{l}\text { KU212178 } \\
\text { KU212180 }\end{array}$ & $\begin{array}{l}\text { KU212197 } \\
\text { KU212181 }\end{array}$ \\
\hline Brachylecithum lanicola (Layman, 1926) & $\begin{array}{l}\text { Red-backed shrike } \\
\text { Lanius collurio }\end{array}$ & Czech Republic, Central Moravia & KU212183 & KU212194 \\
\hline Brachylecithum lobatum (Railliet, 1900) & $\begin{array}{l}\text { the carrion crow } \\
\text { Corvus cornae }\end{array}$ & Czech Republic, Central Moravia & AY222260 & - \\
\hline Brachylecithum lobatum (Railliet, 1900) & $\begin{array}{l}\text { Rook } \\
\text { Corvus frugilegus }\end{array}$ & Czech Republic, Central Moravia & KU212200 a & KU212199 \\
\hline Brachylecithum lobatum (Railliet, 1900) & $\begin{array}{l}\text { Eurasian sparrowhawk } \\
\text { Accipiter nisus }\end{array}$ & Poland, Baltic coast & KU212179 & KU212198 \\
\hline $\begin{array}{l}\text { Brachylecithum lobatum (Railliet, 1900) sporocysts with } \\
\text { cercariae }\end{array}$ & $\begin{array}{l}\text { White-lipped snail } \\
\text { Cepaea hortensis }\end{array}$ & Poland, Mazovia & KU212189 & KU212190 \\
\hline Brachylecithum lobatum (Railliet, 1900) metacercaria & $\begin{array}{l}\text { White-lipped snail } \\
\text { Cepaea hortensis }\end{array}$ & Poland, Mazovia & KU212187 & KU212186 ${ }^{\mathrm{a}}$ \\
\hline $\begin{array}{l}\text { Brachylecithum lobatum (Railliet, 1900) sporocysts with } \\
\text { cercariae }\end{array}$ & $\begin{array}{l}\text { Brown-lipped snail } \\
\text { Cepaea nemoralis }\end{array}$ & Poland, Mazovia & KU212188 & KU212185 \\
\hline Brachylecithum strigis (Yamaguti, 1939) & $\begin{array}{l}\text { European scops owl } \\
\text { Otus scops }\end{array}$ & Czech Republic, Central Moravia & KU212195 & KU212196 ${ }^{\mathrm{a}}$ \\
\hline Dicrocoelium dendriticum (Rudolphi, 1819) & $\begin{array}{l}\text { Bobak marmot } \\
\text { Marmota bobak }\end{array}$ & Ukraine & AF151939 & - \\
\hline Lyperosomum collurionis (Skrjabin and Isaichikov, 1927) & $\begin{array}{l}\text { Eurasian blackcap } \\
\text { Sylvia atricapilla }\end{array}$ & Czech Republic, Central Moravia & AY222259 & - \\
\hline Lyperosomum collurionis (Skrjabin and Isaichikov, 1927) & $\begin{array}{l}\text { Eurasian blackcap } \\
\text { Sylvia atricapilla }\end{array}$ & Czech Republic, Central Moravia & KU212193 & $\mathrm{KU} 212192^{\mathrm{a}}$ \\
\hline $\begin{array}{l}\text { Lyperosomum transcarpathicus Bychowskaja- } \\
\text { Pavlovskaja and Kulakova, } 1978\end{array}$ & $\begin{array}{l}\text { Eurasian pygmy shrew } \\
\text { Sorex minutus }\end{array}$ & Ukraine & AF151943 & - \\
\hline $\begin{array}{l}\text { Macvicaria magellanica Laskowski, Jeżewski and } \\
\text { Zdzitowiecki, } 2013\end{array}$ & $\begin{array}{l}\text { Nototheniid fish } \\
\text { Patagonotothen spp. }\end{array}$ & Antarctica & KU212191 ${ }^{\mathrm{a}}$ & - \\
\hline
\end{tabular}

${ }^{\mathrm{a}}$ New sequences generated by this study

Table 2 Sequences of primers used in the analyses

\begin{tabular}{lll}
\hline Name & Sequence $\left(5^{\prime}-3^{\prime}\right)$ & Reference \\
\hline $\begin{array}{l}\text { cox } 1 \text { PCR and sequencing primers } \\
\text { COIA3 }\end{array}$ & GTTGCATGATACTTGGTTTGTTG & Present study \\
COITR1 & CAACAACAAACCAAGTATCATG & Laskowski and Rocka 2014 \\
COIDF1 & TATTGTTTCAGCATATGTTTTG & Present study \\
COIDR1 & CAACAAACCAAGTATCATGCAAC & Present study \\
28 PCR primers & & \\
DLS1 & ACCCGCTGAACTTAAGCATATCACTAAGC & Laskowski and Rocka 2014 \\
1500R & GCTATCCTGAGGGAAACTTCG & Tkach et al. 2003 \\
28 S sequencing primers & \\
DF400 & AAACCGCTCAGAGGTAAGC & Present study \\
$1100 \mathrm{R}$ & CTTGGTCCGTGTTTCAAGACGGG & Present study \\
\hline
\end{tabular}


Macvicaria magellanica (cod icefish)

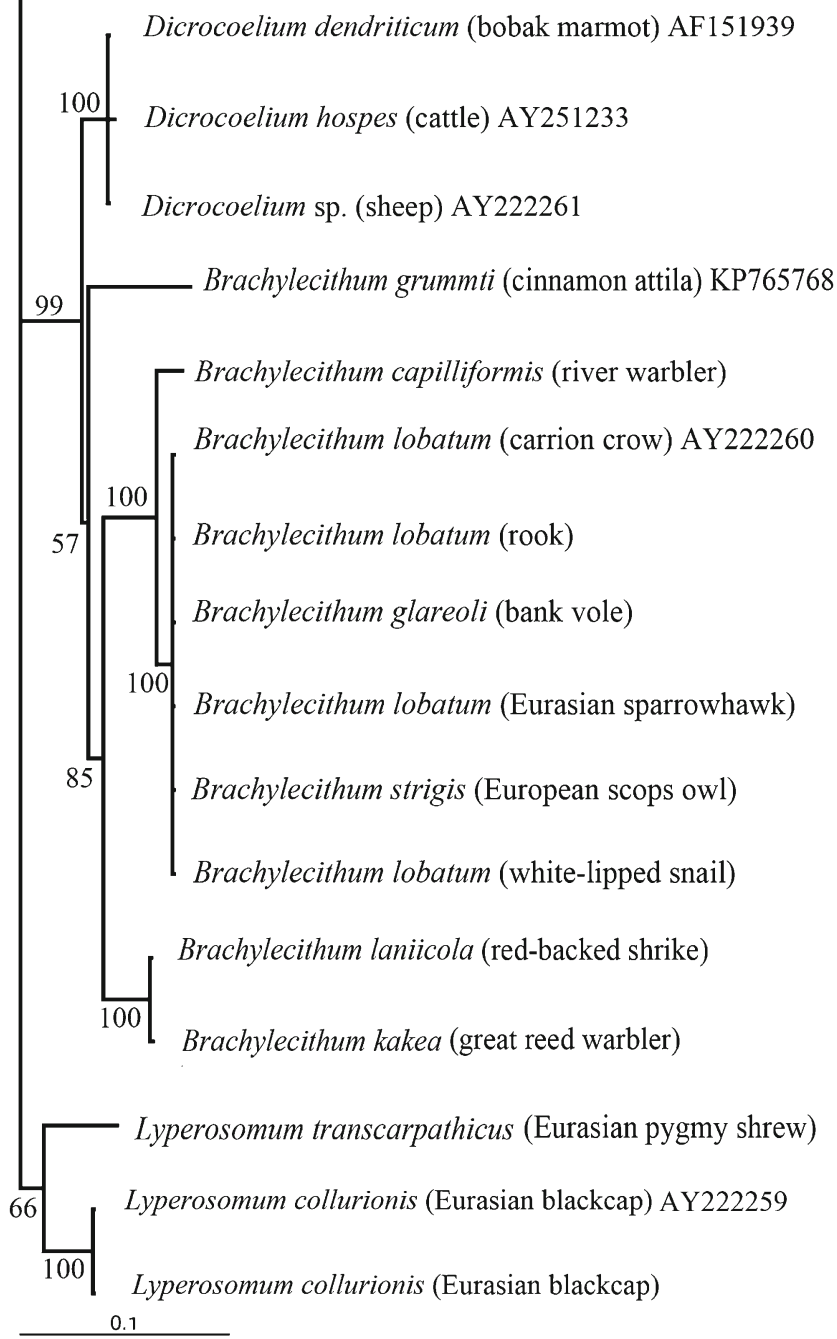

Fig. 2 Bayesian analysis of partial sequences of the 28S rDNA gene of 16 members of Dicrocoeliidae. The tree constructed with MrBayes using the GTR $+\mathrm{G}$ model. The analysis was run for one million generations, with 250,000 generations as burn-in. Scale bars: number of substitutions per site. Nodal support is indicated as Bayesian posterior probabilities. Host species are provided in parentheses. Outgroup $-M$. magellanica (Opecoelidae)

divergence between the species of Brachylecitum ranged from 0.001 to 0.077 base substitution differences per site for B. kakea/B. laniicola and B. capilliformis/B. grummti, respectively.

The cox 1 sequence analysis yielded a generally similar tree topology, but the isolates of B. lobatum/strigis from bird hosts clustered in a clade distinct from the rodent-derived Brachylecithum glareoli (Fig. 3). The topology of the tree generated by the Bayesian inference in the concatenated dataset confirmed the relationships within Brachylecithum observed for the mitochondrial cox 1 gene (Fig. 4). According to our results, we propose to synonymize $B$. strigis with B. lobatum. The genetic differences observed for $28 \mathrm{~S}$ rDNA and cox 1 confirm the independent status of $B$. capilliformis and indicate a distinct group within the genus Brachylecithum, containing B. kakea and B. laniicola.

The cercarial and metacercarial isolates from the snails showed $100 \%$ similarity to $B$. lobatum in both genetic markers. This places the larval stages in B. lobatum. This is the observation of Cepaea snails as intermediate hosts of this trematode.

\section{Discussion}

The phylogenetic analysis presented in this study is still limited to a few representatives of the family Dicrocoeliidae; however, it provides a strong support for the DicrocoeliumBrachylecithum clade and the relationship between Lyperosomum spp. and Dicrocoelium-Brachylecithum shown in two recent papers (Ribas et al. 2012; Hildebrand et al. 2015).

The phylogenetic tree based on the concatenated $28 \mathrm{~S}$ rDNA and cox 1 sequences shows a close relationship between B. capilliformis and B. lobatum; likewise, B. kakea and B. laniicola are sister groups. Perhaps, the fact could be explained by their host ecology. In their long-term study, Sitko et al. (2006) recorded B. kakea and B. lanicola from Acrocephalus arundinaceus and Lanius collurio only in spring, just after the birds' arrival (J. Sitko, unpublished data), suggesting that they were non-European species, unable to complete their life cycle in the nesting grounds.

Future molecular studies including more representatives of different genera, for example, Brachylecithum and Lyperosomum, as well as related species, may explain the relationships within the Dicrocoeliidae and their subfamilies. These analyses would better clarify the phylogenetic position of the dicrocoeliid genera and also the relationships among the species currently included in some of them, i.e., Brachylecithum, Lutztrema, or Lyperosomum, as shown by the results of Hildebrand et al. (2015). According to the previously mentioned and current studies, a similar molecular analysis of non-European Brachylecithum species related to the B. grummti and B. kakea/B. laniicola group, and also Lutztrema spp., is necessary to understand the relationships within this large genus.

The molecular characteristics of representatives of Brachylecithum originating from different hosts show that B. lobatum is widely distributed and occurs in birds of the central part of Europe. It parasitizes various hosts, not necessarily closely related to each other, i.e., Corvidae, Accipitridae, or Strigidae. In contrast, the remaining members of Brachylecithum analyzed in this study seem to be more host-specific.

The molecular identification of $B$. lobatum in land snails of the genus Cepaea is the first indication of the intermediate 
Fig. 3 Bayesian analysis of the partial mitochondrial proteincoding gene cox 1 (data as amino acids) derived from nine isolates of Brachylecithum spp. Tree constructed using the HKY $+\mathrm{G}$ model. The analysis was run for two million generations; 500,000 generations were discarded as burn-in. The branch-length scale indicates the number of substitutions per site. Nodal support is indicated as Bayesian posterior probabilities. Host species are provided in parentheses. OutgroupLyperosomum collurionis
Fig. 4 Bayesian analysis of partial sequence $28 \mathrm{~S}$ rDNA + partial sequence $\operatorname{cox} 1$ data of nine members of the Brachylecithum genus. Tree constructed with MrBayes using the GTR $+\mathrm{G}$ model for 28S rDNA and HKY + $\mathrm{G}$ for $\operatorname{cox} 1$. The analysis was run for one million generations, with 250,000 generations as burn-in. Scale bars: number of substitutions per site. Nodal support is indicated as Bayesian posterior probabilities. Host species are provided in parentheses. OutgroupLyperosomum collurionis
Lyperosomum collurionis (Eurasian blackcap)

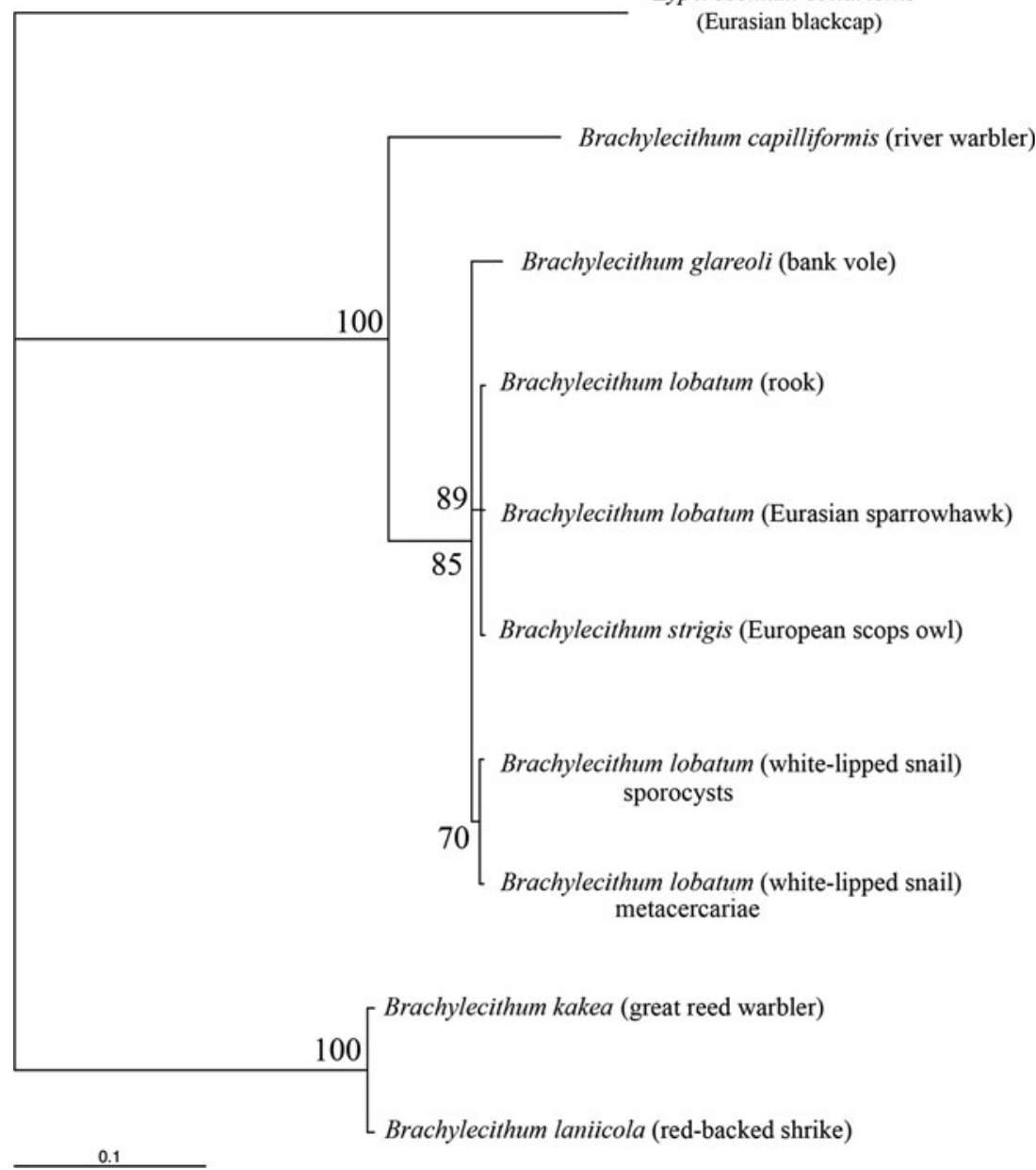

Lyperosomum collurionis (Eurasian blackcap)

Brachylecithum capilliformis (river warbler)

Brachylecithum glareoli (bank vole)

Brachylecithum lobatum (rook)

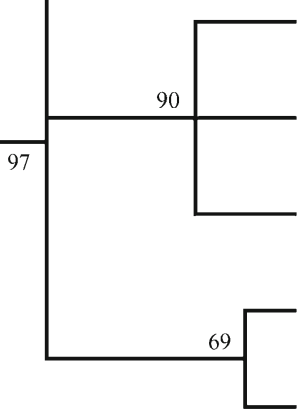

Brachylecithum lobatum (Eurasian sparrowhawk)

Brachylecithum strigis (European scops owl)

Brachylecithum lobatum (white-lipped snail) sporocysts and cercariae

Brachylecithum lobatum (white-lipped snail) metacercariae

100

Brachylecithum laniicola (red-backed shrike) 

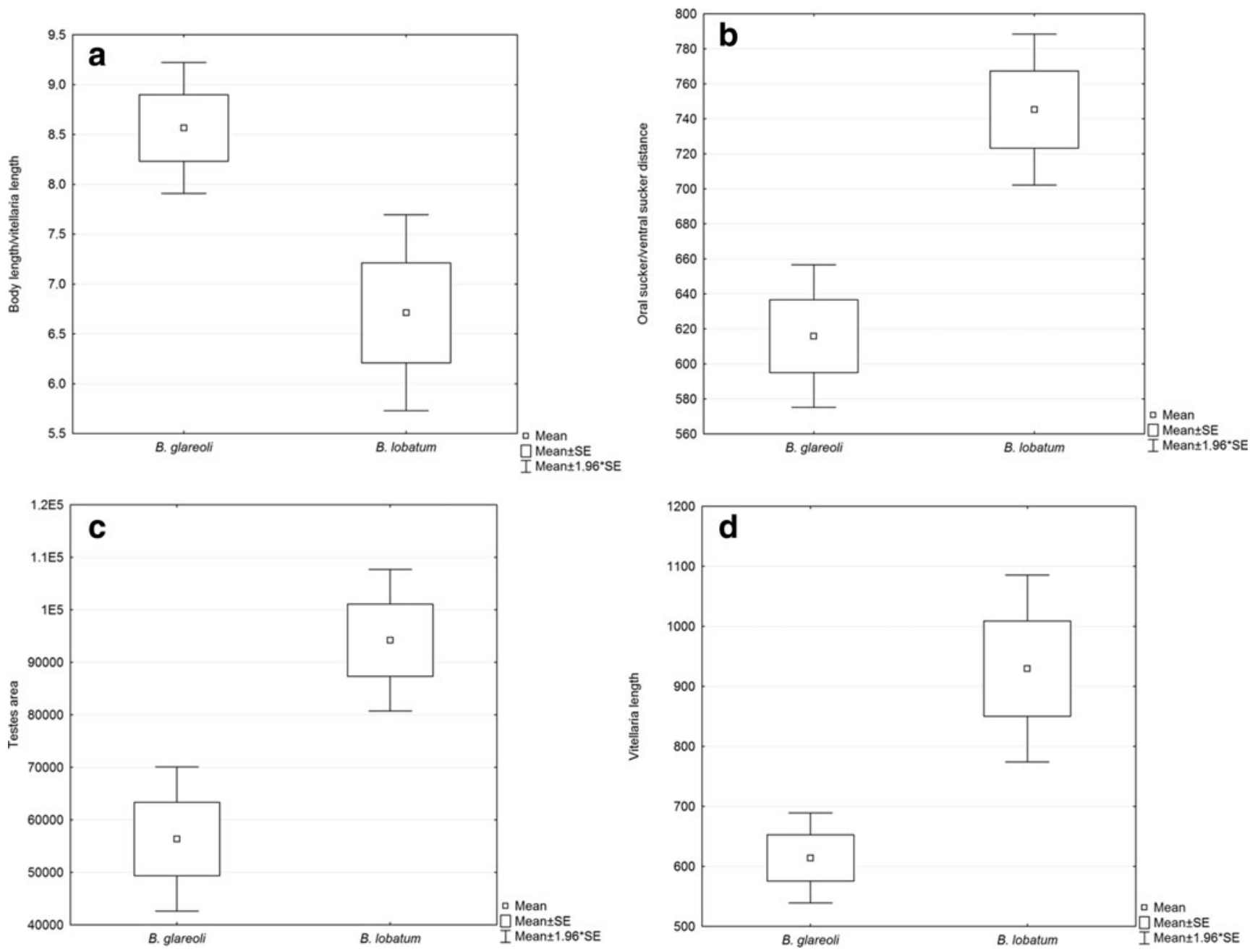

Fig. 5 Comparison of morphometric characters of B. glareoli and B. lobatum. a Ratio of body length to vitellaria length, $\mathbf{b}$ distance between oral and ventral suckers, $\mathbf{c}$ testis area, and $\mathbf{d}$ vitellaria length

host for this species. Additionally, it is the first report on all larval stages of $B$. lobatum found in the wild. All the previous studies on life cycles of members of this genus were performed in experimental conditions without obtaining the metacercariae (Carney 1970, 1972, 1974; Denton 1945; Kingston 1965; Timon-David 1957). Only one life cycle of Brachylecithum was described completely, i.e., B. mosquenis; however, according to the redescription by Sitko and Okulewicz (2002), the species is actually a representative of the genus Brachydistomum and uses ants as the second intermediate hosts. That has never been observed in any other Brachylecithum species, despite the attempts (Carey 1972). The simultaneous presence of sporocysts with welldeveloped cercariae and metacercariae (encysted inside the sporocyst) in the same snail specimen (Fig. 1) is the first case of life cycle abbreviation in the Dicrocoeliidae (Poulin and Cribb 2002). According to Poulin and Cribb (2002) and Galaktionov and Dobrovolskij (2003), there are a few known types of truncations of life cycles among trematodes, including the abovementioned. The authors

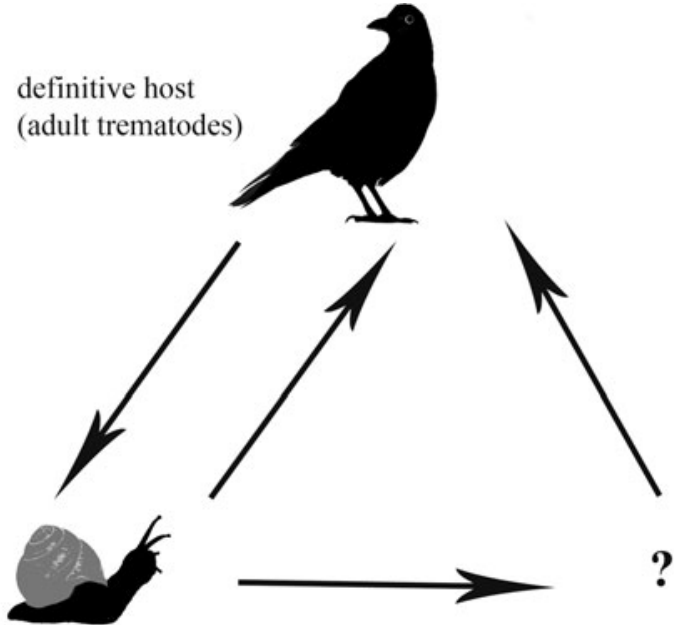

first (and second) intermediate host (sporocysts, cercariae unknown second intermediate host and metacercariae)

(metacercariae)

Fig. 6 Possibilities of the B. lobatum life cycle 
proposed "the rare or missing host hypothesis" to explain this shorter cycle by seasonal migrations or fluctuations in host abundance.

B. glareoli, a dicrocoeliid parasitizing small mammals, was described as a distinct species based on morphological discriminant analysis of all known dicrocoeliids recorded from rodents or insectivores (Hildebrand at al. 2007); the same is true of a few Brachylecithum species which occur in Holarctic birds and show partial similarity in such morphological characters as position and shape of gonads or shape and proportion of suckers. However, in our phylogenetic analyses, B. glareoli showed a high level of similarity with $B$. lobatum, with five nucleotides differing among the cox 1 sequences, compared to B. glareoli and isolates of B. lobatum from different (definitive and intermediate) hosts. Additionally, we analyzed the morphological traits of the two species. Overall, 20 individuals of both species were measured as described by Hildebrand et al. (2007). The mean values were analyzed using $t$ test (Statistica 10). The two species differ significantly in the most important taxonomic features. B. lobatum has vitellaria $30 \%$ longer than B. glareoli $(p<0.01)$, almost $50 \%$ larger testes $(p<0.01)$, and $20 \%$ longer distance between oral and ventral suckers $(p<0.001)$ (Fig. 5). Considering both statistical and molecular data, we recognize $B$. glareoli as a still valid taxon.

The reported molecular similarity between B. lobatum and $B$. glareoli may suggest that the B. glareoli-bank vole association is probably quite a new host-parasite relationship. This new association is probably derived from the well-established and common system of $B$. lobatum-bird host, as a result of host switching. In this study, we presented the evidence that $B$. lobatum could abbreviate its life cycle in some environmental conditions and probably could complete the life cycle in a way which is typical of the vast majority of digeneans, i.e., involving three hosts (Fig. 6). It seems more likely that the shortening of the life cycle of $B$. lobatum, which was recorded in the present study, was one of the factors which facilitated the switch of the fluke between bird and rodent hosts.

Acknowledgments This study was supported by the National Science Centre, Poland, project no. N303 580939. The authors are grateful to Dr. Paul Bates from the University of Minnesota Duluth and Prof. Beata Pokryszko from the University of Wrocław for the review and for revising the English.

\section{Compliance with ethical standards}

Conflict of interest The authors declare that they have no competing interests.

Open Access This article is distributed under the terms of the Creative Commons Attribution 4.0 International License (http:// creativecommons.org/licenses/by/4.0/), which permits unrestricted use, distribution, and reproduction in any medium, provided you give appropriate credit to the original author(s) and the source, provide a link to the Creative Commons license, and indicate if changes were made.

\section{References}

Cai Z, Zhang Y, Ye X (2012) Phylogenetic relationships of the genus Eurytrema from domestic and wild animal based on 18S rRNA sequences. Parasitol Res 111:1637-44. doi:10.1007/s00436-012-3002-y

Carney WP (1970) Brachylecithum mosquensis: infections in vertebrate, molluscan, and arthropod hosts. T Am Microsc Soc 89:233-250

Carney WP (1972) Studies on the life history of Brachylecithum myadestis sp. n. (Trematoda: Dicrocoeliidae). J Parasitol 58:519-523

Carney WP (1974) Studies on the life history of Brachylecithum stunkardi (Pande, 1939) (Trematoda: Dicrocoeliidae). P Helm Soc Wash 41:139-144

Darriba D, Taboada GL, Doallo R, Posada D (2012) jModelTest 2: more models, new heuristics and parallel computing. Nat Methods 9:772

Denton JF (1945) Studies on the life history of Brachylecithum americanum n. sp., a liver fluke of passerine birds. J Parasitol 31:131-141

Galaktionov KV, Dobrovolskij AA (2003) The biology and evolution of trematodes. An essay on the biology, morphology, life cycles, transmission, and evolution of digenetic trematodes. Kluwer Academic Publ, Boston, Dordrecht, London

Guindon S, Gascuel O (2003) A simple, fast, and accurate algorithm to estimate large phylogenies by maximum likelihood. Syst Biol 52: 696-704

Hildebrand J, Okulewicz J, Popiołek M (2007) A new dicrocoeliid from the bank vole Clethrionomys glareolus (Rodentia, Microtidae). J Parasitol 93:151-154

Hildebrand J, Pulis EE, Tkach VV (2015) Redescription and phylogenetic relationships of the rare Lyperosomum sarothrurae Baer, 1959 (Digenea: Dicrocoeliidae). Acta Parasitol 60:371-377. doi:10. 1515/ap-2015-0052

Kingston N (1965) On the life cycle of Brachylecithum orfi Kingston and Freeman, 1959 (Trematoda: Dicrocoeliidae), from the liver of the ruffed grouse, Bonasa umbellus L. Infections in the vertebrate and molluscan hosts. Can J Zool 43:745-764

Laskowski Z, Rocka A (2014) Molecular identification larvae of Onchobothrium antarcticum (Cestoda: Tetraphyllidea) from marbled rockcod, Notothenia rossii, in Admiralty Bay (King George Island, Antarctica). Acta Parasitol 59:767-772

Laskowski Z, Jeżewski W, Zdzitowiecki K (2013) Description of a new opecoelid trematode species from notothenioid fish in the Beagle Channel (sub-Antarctica). J Parasitol 99:487-489

Maurelli MP, Rinaldi L, Capuano F, Perugini AG, Veneziano V, Cringoli G (2007) Characterization of the 28S and the second internal transcribed spacer of ribosomal DNA of Dicrocoelium dendriticum and Dicrocoelium hospes. Parasitol Res 101:1251-1255. doi:10.1007/ s00436-007-0629-1

Olson PD, Cribb TH, Tkach VV, Bray RA, Littlewood DTJ (2003) Phylogeny and classification of the Digenea (Platyhelminthes: Trematoda). Int J Parasitol 33:733-755. doi:10.1016/S00207519(03)00049-3

Page RDM (1996) TreeView: an application to display phylogenetic trees on personal computers. Comput Appl Biosci 12:357-358. doi:10. 1093/bioinformatics/12.4.357

Panin V (1984) Dicrocoeliid trematodes of world fauna. Nauka Kazakhskoi SSR, Alma Ata [In Russian]

Pojmańska T (2008) Family Dicrocoeliidae Looss, 1899. In: Bray RA, Gibson DI, Jones A (eds) Keys to the Trematoda, vol 3. CABI Publishing and The Natural History Museum, London, pp 233-260

Poulin R, Cribb TH (2002) Trematode life cycles: short is sweet? Trends in Parasitology 18:176-183. doi:10.1016/S1471-4922(02)02262-6

Ribas A, Makundi RH, Goüy de Bellocq J (2012) Paraconcinnum leirsi n.sp. (Trematoda: Dicrocoeliidae) from rodents in Tanzania and its phylogenetic position within the dicrocoeliids. African Zoology 47: 326-331. doi:10.3377/004.047.0219 
Ronquist F, Huelsenbeck JP (2003) MrBayes 3: Bayesian phylogenetic inference under mixed models. Bioinformatics 19:1572-1574. doi: 10.1093/bioinformatics/btg180

Rysavy B (1960) Prispvek k poznani motolic cizopasicich u ptaku v Ceskoslovensku (Beitrag zur Kenntnis der bei Vogeln in der Tschechoslowakei parasitar auftretenden Trematoden). Cesk Parasitol 7:271-283

Sitko J, Okulewicz J (2002) Redescription and systematic status of Brachydistomum ventricosum (Rudolphi, 1809) comb. n. (Trematoda: Dicrocoeliidae) parasitising passeriform birds. Helminthologia 39:103-110

Sitko J, Faltynkova A, Scholz T (2006) Checklist of the trematodes (Digenea) of birds of the Czech and Slovak Republics. Academia, Praha

Tamura K, Nei M, Kumar S (2004) Prospects for inferring very large phylogenies by using the neighbor-joining method. P Natl Acad Sci USA 101:11030-11035
Tamura K, Stecher G, Peterson D, Filipski A, Kumar S (2013) MEGA6: Molecular Evolutionary Genetics Analysis version 6.0. Mol Biol Evol 30:2725-2729

Timon-David J (1957) Recherches sur le developpement experimental de Brachylecithum alfortense (A. Railliet) R. Ph. Dollfus 1954, Trematode Dicrocoeliide parasite des voies biliares de la Pie. Ann Parasitol Hum Comp 32:353-368

Tkach V, Pawlowski J, Mariaux J, Swiderski Z (2001) Molecular phylogeny of the suborder Plagiorchiata and its position in the system of Digenea. In: Littlewood DTJ, Bray RA (eds) Interrelationships of Platyhelminthes. Taylor \& Francis, London, pp 186-193

Tkach VV, Littlewood DTJ, Olson PD, Kinsella JM, Świderski Z (2003) Molecular phylogenetic analysis of the Microphalloidea Ward, 1901 (Trematoda: Digenea). Syst Parasitol 56:1-15. doi:10.1023/ A: 1025546001611 